\title{
Afetividade e/na educação: sentir e expressar na experiência (est)ética - contribuições da filosofia espinosana
}

Lavínia L. S. Magiolino

Universidade Bandeirante Anhanguera, São Paulo/SP

\section{Resumo}

O conhecimento produzido nos diversos campos da ciência e conhecimento (Biologia, Antropologia, Psicologia, Filosofia, Neurologia) impacta a Educação, seja na produção do conhecimento, seja na atividade pedagógica. Em meio às contribuições nessa área, se faz notar a ideia de controle das emoções em parte das estratégias de intervenção, estritamente cognitivas, que desvelam uma fundamentação cartesiana. Partindo dessas constatações, argumentamos sobre a importância da elaboração de Espinosa sobre os afetos (definições de afeto, causa adequada e inadequada, passividade e atividade, afecção) e as (im)possibilidades de domínio da conduta para uma compreensão da dinâmica afetiva e de seu processo de conhecimento. Tomamos como lócus de elaboração o trabalho do ator de teatro na sala de ensaio e uma situação de agressão em sala de aula, em busca de abrir novas picadas no caminho para uma educação que não se fundamenta no controle, mas no conhecimento e no desenvolvimento das emoções, uma educação sensível e expressiva.

Palavras-chave: Afetividade; Espinosa; Educação.

\begin{abstract}
The knowledge produced in the various fields of science (biology, anthropology, psychology, philosophy, neurology) impacts the education, either in knowledge production, either in pedagogical activity. Amid the contributions in this area, if notes the idea of controlling emotions in intervention strategies, strictly cognitives, that reveal Cartesian principles. Based on these considerations, we argue about the importance of Spinoza's conception of affections (definitions of affection, cause adequate and inadequate cause, passivity and activity, and affections process) and the (im) possibilities of the control of the conduct to understanding the dynamics of emotional process and its knowledge. We take as the locus of elaboration, the work stage actor in the rehearsal room and a situation of aggression in the classroom, seeking to open new ways to conceiving an education that is not based on control, but in the knowledge and development of emotions, an sensitive and expressive education.
\end{abstract}

Keywords: Affection; Espinosa; Education. 


\section{Circunscrevendo a questão da educação e a afetividade: preâmbulos e provocações}

A professora estava passando na lousa um texto que acabara de ler com as crianças. Dois meninos começam uma discussão. Quando ela se vira para a turma, o Vitor está em pé, segurando o Wallace pela camisa. Ela vai até lá para separar, mas antes que chegue, Vitor dá um soco no colega, fazendo seu nariz sangrar. Os dois estão muito nervosos. Gritam e choram. Ela consegue separá-los. Um dos meninos segura Wallace. Ela abraça o Vitor por trás, ele levanta os pés e chuta as carteiras em volta. As outras crianças se levantam assustadas. A professora pede para tirarem o Wallace da sala e chamarem alguém na secretaria. Os dois gritam e dizem que vão acabar um com o outro, bater, matar. Ninguém aparece para auxiliar (Material recortado de registro em diário de campo ${ }^{1}$ ).

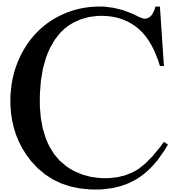

enas como essa que nos serve de epígrafe têm se tornado cada vez mais comuns nas salas de aula de nossas escolas nas mais diversas esferas sociais, levando inúmeros pesquisadores, dos mais diversos campos da ciência e do conhecimento, a se voltarem para a questão da violência, da agressividade e, com ela, à questão das emoções e da afetividade.

No âmbito da educação, mais particularmente, temos encontrado tentativas de enfrentamento da questão marcadas por uma discussão em torno da afetividade (Leite, 2006; Arantes, 2003). O livro Afetividade e Práticas Pedagógicas, organizado por Leite (2006), apresenta diversos trabalhos ancorados numa perspectiva denominada históricocultural que exploram a questão da afetividade em diversas situações de ensino, procurando dar visibilidade, sobretudo, à importância da dimensão afetiva na relação professor-aluno e nos processos de aprendizagem. Afetividade na escola, ao contrário, uma coletânea organizada por Arantes (2003), inclui o trabalho de autores de diferentes perspectivas teóricas, trazendo a contribuição destas para a educação.

Assim, produções mais recentes sobre essa temática nos remetem a uma retomada de contribuições fundamentais de autores como Freud, Piaget, Vigotski, Wallon e, mais recentemente, Damásio, em diferentes campos do conhecimento como psicanálise, biologia, psicologia, neurologia.

Nesse contexto, diversos estudos têm sido dedicados às práticas, metodologias ou tecnologias educacionais e também ao estudo do comportamento e do psiquismo humano, tendo a afetividade como foco central.

\footnotetext{
${ }^{1}$ A pesquisa de campo foi realizada durante o curso de Mestrado em Educação, realizado na Unicamp, mas acabou culminando num trabalho teórico: a dissertação intitulada Emoções: uma discussão sobre modos de conceber e teorizar, sob orientação de Ana Luiza B. Smolka, que contou com o apoio da CAPES.
} 
Nesse campo, do ponto de vista mais pragmático, um dos trabalhos que têm tido destaque é Inteligência Emocional e a proposta de alfabetização emocional de Goleman (2005). O autor coloca essa proposta tematizando a agressão no tópico intitulado “domando a agressão". Ele relata o caso de um garoto, tido como valentão em sua escola primária: era o garoto que roubava o dinheiro da merenda e tomava a bicicleta dos colegas, preferia bater a conversar, o "arruaceiro clássico". E, por fim, o autor atesta que garotos como esse são "visivelmente perturbados" e portadores "distorções perceptivas" que surgem já na infância e marcam a sua ação na vida adulta. O autor adverte ainda que estudos que acompanharam crianças desde os anos pré-escolares até a adolescência constatam que "a tendência para o crime aparece surpreendentemente cedo na vida dessas crianças" e que "protótipo do caminho para a violência e a criminalidade começa com crianças agressivas e difíceis de lidar na primeira e segunda séries" (Goleman, 2005, p. 88).

Em meio a inúmeras referências a estudos e programas, o autor ressalta a necessidade e a eficácia de se prever e lidar com problemas como a depressão e coloca, então, a importância de uma alfabetização emocional. Nos programas que servem de modelo para o ensino de Inteligência Emocional, entre os tópicos que são ensinados, encontram-se a autoconsciência e o controle das emoções. As atividades compreendem: tarefas como a de passar por uma prova oral com uma pergunta que pode, por exemplo, levar o aluno a versar sobre uma resposta adequada para ajudar um amigo na resolução de um conflito sobre alguém que o pressiona para tomar drogas; a leitura de emoções em expressões faciais para controle de impulsos; o trabalho em seis etapas de controle em que se exibe um cartaz com um sinal de trânsito com a lógica do pare e pense; a identificação de sentimentos a partir de fotos de rostos exibindo uma das chamadas emoções básicas - alegria, tristeza, ira, surpresa, medo e nojo - e uma descrição da atividade muscular facial por baixo de cada um, por exemplo ${ }^{2}$.

Para o autor, essa lição básica de ligar um nome a um sentimento e este a uma expressão facial é fundamental, pois serve como antídoto para os lapsos comuns do que é denominado, por ele, como alfabetização emocional. "Os valentões dos pátios de recreio, lembrem-se, muitas vezes atacam irados porque interpretam mal mensagens e expressões neutras como hostis, e as meninas que contraem distúrbios de alimentação

${ }^{2} \mathrm{~A}$ atividade se baseia na pesquisa de Paul Ekman sobre expressão facial das emoções que, como o próprio Goleman adverte, é ensinada nos cursos universitários de introdução à psicologia da maioria das universidades e raramente na escola primária. 
não distinguem ira e ansiedade de fome" (Goleman, 2005, p.42). Nessa proposta, a alfabetização emocional surge como prevenção a um problema específico: a violência. A ideia de controle das emoções é pedra angular de todas as estratégias de intervenção.

A contribuição dos trabalhos mencionados reside ora no fato de apontarem que afeto e cognição são entendidos como igualmente importantes ao desenvolvimento e à aprendizagem, num esforço de superação do dualismo, ora por oferecerem alternativas diferenciadas para se trabalhar com as emoções no campo prático.

Contudo, com relação a esse último ponto embora haja soluções criativas, a maioria delas incide no fato de treinar, desenvolver competências e habilidades, dominar e controlar por meio de estratégias, quase sempre, estritamente cognitivas.

Assim, apesar das contribuições, no campo prático, vemos emergir uma concepção de educação centrada: no ensino e controle das emoções - sobretudo, as consideradas, a priori como negativas; incentivo às emoções também consideradas $a$ priori como positivas; afetismo (algo como a proclamação do afeto nas relações de ensino) e pedagogização ou didatização das emoções.

Emergem destas considerações alguns questionamentos com relação ao modo como se concebem afetos, sentimentos e emoções e, com isso, ao modo como essas se concepções se desdobram no campo da pesquisa e da prática educacional. Assim, indagamos, ao trabalharem com a noção de que as emoções ou os afetos são a priori positivos ou negativos e que precisam ser controlados, domados e dominados, que premissas, inspirações ou ideias fundamentam essas propostas?

Tomando essa indagação como ponto de partida, propomo-nos, nesse texto, a enfrentar a questão da afetividade na educação, dedicando-nos à discussão das ideias de Espinosa sobre o processo de afecção, que consideramos central para a superação de uma abordagem mecanicista, funcional e pragmática no campo educacional - e que, como esperamos desvelar, é ainda de inspiração cartesiana.

Em busca de refletir sobre a questão aqui colocada, explicita-se a ideia de retomar a elaboração de Espinosa sobre afeto e afecção e as (im)possibilidades de domínio da conduta. Compreender essa elaboração conceitual implica pensar nas definições de Espinosa: causa adequada e inadequada, afeto e afecção, tendo em vista a dinâmica de afetividade e passividade. Ao tomar essa elaboração como objeto de reflexão argumentamos sobre a possibilidade de compreender a experiência subjetiva das 
emoções, sua expressão e as (im)possibilidades que se desdobram para o conhecimento e trabalho educacional.

Não é intenção desse ensaio uma abordagem de Espinosa com base em análises do texto do filósofo. Ao tomar como ponto de suspeição e indagação o modo como a temática da afetividade vem sendo abordada na educação, trata-se de explicitar algumas de suas noções/ideias para elaborar conceitualmente sobre a questão numa trama que envolve, sobretudo, a arte e a pedagogia.

Tomamos, para tanto, como lócus de elaboração da questão, a sala de ensaio de uma companhia de teatro e uma sala de aula de Ensino Fundamental em uma escola pública num exercício analítico de parte de nosso material empírico coletado, procurando dar visibilidade à dinâmica da afecção em sua complexidade.

\title{
A dinâmica afetiva: expressão e sensação
}

\author{
Oh, que ignóbil eu sou, que escravo abjeto! \\ Não é monstruoso que esse ator aí, \\ Por uma fábula, uma paixão fingida, \\ Possa forçar a alma a sentir o que ele quer, \\ De tal forma que seu rosto empalidece, \\ Tem lágrimas nos olhos, angústia no semblante, \\ A voz trêmula, e toda sua aparência \\ Se ajusta ao que ele pretende? \\ [...] Mas eu, Idiota inerte, alma de lodo \\ [...] Ó, vingança! \\ Mas que asno eu sou! Bela proeza a minha. \\ $\mathrm{Eu}$, filho querido de um pai assassinado, \\ Intimado à vingança pelo céu e o inferno, \\ Fico aqui, como uma marafona, \\ Desafogando minha alma com palavras!
}

(William Shakespeare, Hamlet)

Hamlet, no solilóquio que encerra o segundo ato da peça, reconhece-se como ser ignóbil e desprovido de vontade, um escravo, um ser abjeto por não ser capaz de forçar a sua alma a sentir o que ele quer. Ele admira-se, além disso, com o poder que um ator que representa uma cena de $\mathrm{Hécuba}^{3}$ tem ao conformar seu rosto, seu corpo, sua voz a uma expressão patente de tristeza. Aqui, ao que parece, a alma se ajusta a intenção, é

\footnotetext{
${ }^{3}$ Na mitologia grega e romana, Hécuba é mulher de Príamo, que deu à luz a dezenove filhos. Em Tróia, assistiu à morte de quase todos, tendo visto seu marido ser trucidado. Viveu como escrava e vingou-se da morte de alguns de seus entes e, então, foi apedrejada pelo povo e mordeu os que a atingiam. Consta que, por isso, foi transformada em cadela.
} 
moldada pelos desígnios do pensamento, segue o comando da razão sem percalços, sem desvios.

Nessa primeira estrofe deparamo-nos com questões arcaicas e arraigadas dicotomias...: razão e emoção, controle e vontade, sensação e expressão.

Hamlet expressa um desejo, dos mais íntimos do ser humano: controlar suas emoções, afetos, dominá-las, conformá-las segundo a sua vontade e subjugá-las à razão.

O controle das paixões almejado por Hamlet nos remete a Descartes, que colocava no plano da existência individual a faculdade de "pensar". O sujeito que, sobretudo, na Idade Média era governado, orientado fundamentalmente pelas leis divinas que se explicitavam com toda a força na hierarquia da igreja católica (Koyré, 1987), agora seria dono de si, senhor de sua vontade e de suas paixões.

Para conhecer e dominar as paixões da alma é preciso, segundo o filósofo, distinguir claramente entre suas funções e as do corpo. As funções do corpo são todas aquelas relacionadas ao calor e ao movimento e as da alma são todas aquelas relacionadas ao pensamento - que, ainda segundo o filósofo, são de dois gêneros: ações da alma e suas paixões.

Aquelas que chamo suas ações são todas as nossas vontades, porque sentimos que vêm diretamente da alma e parecem depender apenas dela; do mesmo modo, ao contrário, pode-se em geral, chamar suas paixões, toda espécie de percepções, ou conhecimentos existentes em nós, porque muitas vezes não é nossa alma que os faz tais como são, e porque sempre os recebe das coisas representadas (Descartes, 1988, p. 84).

O filósofo define as paixões como percepções, sensações e movimentos da alma, provocadas, mantidas e fortalecidas pelos espíritos animais (que, são corpos materiais movidos pelas leis mecânicas, finíssimas partículas de sangue, móveis e quentes, produzidas no coração por destilação) que produzem nos órgãos sensações e movimentos que orientam as funções vitais.

O campo das paixões propriamente ditas está delimitado: "somente as percepções que têm o corpo como causa (os nervos) merecem esse nome" (Descartes, 1988, p.85). Isso porque, o que na alma constitui-se como uma paixão, no corpo constitui-se, comumente, como uma ação.

Tudo o que sentimos existir em nós, e que vemos existir também nos corpos inteiramente inanimados, só deve ser atribuído ao nosso corpo; e, ao contrário, que tudo o que existe 
em nós, e que não concebemos de modo algum como passível de pertencer a um corpo, deve ser atribuído à nossa alma (Descartes, 1988, p. 228).

Descartes toma o corpo (res extensa) e a alma (res cogitans) como substâncias distintas. A filosofia cartesiana, ao cindir a substância em duas partes que se conectam de forma mecânica através de uma glândula, não trata das relações entre mente e corpo, razão e emoção, mas $^{4}$, quando muito, de um domínio da primeira pela segunda.

Espinosa, ao contrário, toma corpo e alma como atributos distintos de uma mesma substância. Assim, ele não identifica a alma a uma res cogitans, de maneira que, a ordem das ações e paixões no nosso corpo é concomitante à ordem das ações e paixões na alma - embora isto não signifique uma relação causal entre alma e corpo (Cf. Espinosa 7, EIII SP2). “[...] Alma e corpo são um só e mesmo indivíduo, concebido ora sob o atributo do pensamento, ora sob o da extensão" (p. 152).

Disso decorrem duas implicações importantes: o corpo não pode determinar a alma a pensar, a alma não pode determinar o corpo ao movimento, pois se trata da mesma coisa apresentada de modo distinto; uma ideia não pode modificar um afeto, um afeto, não pode modificar uma ideia.

Esse modo de pensar e conceber as relações entre alma e corpo e suas funções estabelece uma diferença radical entre Espinosa e Descartes e, por conseguinte, trará implicações radicais às práticas educacionais. Dessa diferença fundante na relação corpo e alma, presente nas duas filosofias, decorre uma compreensão de liberdade humana e do modo como a razão governa ou conduz a emoção que se faz fundamental à educação.

\footnotetext{
${ }^{4} \mathrm{Na}$ hipótese psicofísica de Descartes, fundamentada no fato de que o corpo humano consiste numa complicada máquina cujas partes estão em constante interação, o elemento mais importante, sede da alma e por meio do qual esta se comunica com o organismo, é a glândula pineal. Situada no meio do órgão central do sistema nervoso esta seria, para o filósofo, o local onde os chamados espíritos animais se transformam em sensações e percepções da alma e estas se transformam em movimentos corporais que se propagam até os órgãos. Com esse mecanismo Descartes explica a origem mecânica e natural das paixões: para cada paixão há um estado visceral, um quadro correspondente e bem definido de modificações dos órgãos internos, e, num processo circular, a cada paixão, uma orientação dos espíritos, a cada orientação, uma paixão, num enfoque fisiológico e mecanicista. Espinosa procura superar esse princípio dualista opondo-se ao mesmo. Na Ética $\mathrm{V}$, ao tratar Do poder do entendimento ou da liberdade humana, Espinosa opõe-se a Descartes e a seu argumento sobre união do corpo e da alma por meio da glândula pineal e sobre o fato de que os afetos dependam totalmente da vontade que, por sua vez, pode governá-los de maneira ilimitada. Damásio $(2002,2004)$ mostra, numa perspectiva da neurociência, que o erro de Descartes foi a separação corpo e mente. O neurocientista aponta ainda que a amígdala, como um dos componentes mais importantes do sistema límbico cujos núcleos neuronais possuem uma representação dispositiva que desencadeia a ativação de um estado do corpo - como o medo -, estaria próxima do que Descartes descreve como a glândula pineal. Damásio procura a filosofia de espinosana, mas, para nós, o faz num viés mecanicista que, instiga a questionamentos sobre as relações corpo e mente em suas elaborações sobre emoções e sentimentos.
} 
$\mathrm{Na}$ doutrina cartesiana, a alma governa as afecções à medida que consegue manter-se livre das paixões do corpo e de suas necessidades. Para Espinosa isso é algo do campo da ilusão, pois a liberdade não é estar livre das paixões e dos afetos, mas ter conhecimento deles por intermédio da razão. "Tudo aquilo por que nos esforçamos pela Razão não é outra coisa que conhecer; e a alma, na medida em que usa da Razão, não julga que nenhuma outra coisa lhe seja útil, senão aquela que conduz ao conhecimento" (Espinosa, 1983, p. 240).

Aqui deparamo-nos com o problema da vontade e de sua relação com o conhecimento. Para a doutrina cartesiana, fundamentada na distinção entre intelecto e vontade e na ideia de que o conhecimento é um ato de vontade, essa última é definida em termos de livre-arbítrio. Para Espinosa o conhecimento não é um produto da nossa vontade, à medida que: não há algo que poderia ser apreendido como uma faculdade da alma; e ainda a alma também não existe como algo capaz de armazenar a vontade. A vontade só se realiza como conhecimento à medida que se nega ou se afirma algo.

Espinosa demonstra que, diante de dois estímulos de uma mesma natureza, o homem confia sua ação ao conatus. Ele utiliza-se de um exemplo - retomado por autores como Marx e Vigotski - apresentado por Jean Buridan, um filósofo francês, na primeira metade do século XV. Esse filósofo dizia que, um asno, em uma situação em que houvesse a quantidade de feno numa distância igual a uma porção de água, morreria de fome. Espinosa vai argumentar acerca da impossibilidade de se aplicar essa ideia ao ser humano. Isso, à medida que, ao homem está dada a possibilidade de autodeterminação. (Espinosa, Ética II, escólio da proposição XLIX). Essa ideia é retomada: "Se, no mesmo sujeito, são excitadas duas ações contrárias, deverá necessariamente produzir-se, em ambas ou numa só, uma mudança, até deixarem de ser contrárias" (Espinosa, Ética V, axioma I).

Com essas formulações, Espinosa nos incita a nos atermos à complexa dinâmica das afecções no ser humano.

\section{Os afetos - afeto/ideia, causa adequada e inadequada, passividade e atividade}

É curioso como, numa carta que escreve à princesa Isabel ou Elizabeth ${ }^{5}$, Descartes explica não só o amor, mas boa parte de nossas paixões com base na percepção dessas

\footnotetext{
${ }^{5} \mathrm{O}$ nome da referida princesa aparece nas diferentes traduções da obra como Isabel ou Elizabeth, seguindo a etimologia e significado da palavra em cada língua.
} 
alterações corporais. Reconhece a dificuldade de sua tarefa e, admitindo que não é fácil estudar os fenômenos orgânicos correspondentes a cada paixão, Descartes argumenta que isso se dá porque, no geral, tais fenômenos estão mesclados. Para ele, contudo, a questão se resolve em decompor os fatos, buscar resultados precisos, com ajuda da estatística, da comparação e eliminação - em sua análise o amor é associado à alegria, à tristeza, etc. Para o filósofo a causa das paixões é simples: repousa, no caso da tristeza e alegria, por exemplo, na atividade do estômago que é aumentada ou diminuída, na medida em que nossas primeiras paixões têm, então, uma origem alimentícia.

Espinosa, ao contrário de Descartes, se propõe a demonstrar - geometricamente os afetos. O desejo é o primeiro dos afetos definidos por Espinosa: “O desejo é a própria essência do homem, enquanto está concebida como determinada a fazer algo por uma afecção qualquer nela verificada". Ao se referir ao corpo e à mente, o conatus é denominado apetite; ao se referir apenas à mente, é compreendido, denominado vontade. Deste modo, o conatus é a essência do homem, seguindo-se deste uma série de coisas que servem para a sua conservação; tais coisas, diz Espinosa, o homem é obrigado a fazer. Espinosa ressalta que entre apetite e desejo há apenas uma diferença: o desejo é aplicável geralmente aos homens quando estes têm consciência do seu apetite (Ética III, P 9, escólio). O desejo é, portanto, impulso, esforço, apetite e vontade, os quais variam de acordo com a disposição variável da essência do homem.

Para esclarecer, caberia ainda retomar como Espinosa opera a dedução desse conceito essencial em sua filosofia, o conatus. Este é tido como apetite, desejo, impulso, esforço, mas significa propriamente a essência atual da coisa, que não envolve tempo finito, mas indefinido. Sendo essência, o conatus faz do ser humano uma singularidade por sua própria essência; trata-se, por conseguinte, de uma essência não porque ela realiza, no particular, uma determinada natureza humana que seja universal. O conatus não é meramente uma essência, mas uma essência atual, isto é, uma força em ação constante, e não uma inclinação ou tendência em potência. Suas definições iniciam-se pelo desejo e, desdobram-se em/da alegria e tristeza que são as afecções básicas. Todas as outras afecções se desdobram destas primeiras e vão se diversificando e se complexificando, sendo demonstradas e explicadas de uma maneira em que os contrários se tornam visíveis: o amor é "a alegria acompanhada da ideia de uma causa exterior" e o ódio é "a tristeza acompanhada da ideia de uma causa exterior”; o reconhecimento é "o amor por alguém que fez bem a um outro" e o a indignação é "o 
ódio por alguém que fez mal a um outro"; a consideração "consiste em, por amor, ter por alguém uma opinião acima da justa" e a desconsideração, por sua vez em "por ódio, ter por alguém uma opinião abaixo da justa" (Espinosa, Ética III, definições 6, 7, 19, 20, $21,22)$.

Em determinadas definições Espinosa acrescenta uma explicação ou remete-nos à leitura de outras proposições, escólios ou corolários. É o caso da ira e do sentimento e vingança, por exemplo. "A ira é o desejo que nos incita, por ódio, a fazer mal a quem odiamos. Veja-se a prop. 39"; e "A vingança é o desejo que nos impele, por ódio recíproco, a fazer mal a quem, com igual afeto, nos causou dano" (Espinosa, Ética III, definições 34 e 36).

A definição dos afetos de Espinosa é, como podemos perceber, marcada por uma concepção dialética que traz ainda uma preocupação com a as causas e a natureza dos mesmos.

Importante pontuar, contudo, que em uma das explicações Espinosa faz uma advertência: "sei que esses nomes significam outra coisa no uso corrente. Meu objetivo não é, entretanto, o de explicar o significado das palavras, mas de explicar a natureza das coisas, designando-as por vocábulos que tenham, no uso corrente, um significado que não se afaste inteiramente daquele que quero atribuir-lhes, advertência que basta fazer uma única vez" (Espinosa, Ética III, definição 20, explicação).

Para se compreender os afetos, no entanto, não basta se ater as definiç̧ões assinaladas acima. Para além disso, é necessário apreender as três definições que estão absolutamente articuladas logo na abertura da Ética III. A primeira delas diz respeito às causas. Denomina-se causa adequada aquela cujo efeito pode ser clara e distintamente percebido por ela mesma e causa inadequada ou parcial aquela cujo efeito não pode ser entendido apenas por ela mesma (Ética III, Definição 1).

A segunda definição traz as noções de atividade e passividade. Com elas Espinosa procura afirmar que os homens são ativos ou agem quando dentro ou fora deles se produz algo que eles mesmos sejam "causa adequada" - quando se segue da natureza do homem (dentro ou fora dele) qualquer coisa que possa ser inteligível apenas pela sua natureza com clareza e distinção. Ao contrário, os homens são passivos ou padecem quando qualquer coisa neles se produz ou de sua natureza se segue, de que eles sejam unicamente causa parcial (Ética III, Definição 2). 
Finalmente, na terceira definição é que Espinosa vai adentrar o campo do afeto propriamente dito. O filósofo afirma: "Por afeto compreendo as afecções do corpo, pelas quais sua potência de agir é aumentada ou diminuída, estimulada ou refreada, assim como as ideias dessas afecções" (Ética III, Definição 3).

Esta definição de Espinosa que identifica os afetos às afecções corporais, ou seja, às modificações pelas quais passa um corpo poderia nos remeter a uma cisão, uma dicotomia que, nesse olhar apressado, nos levaria a semelhança com as paixões cartesianas. Entretanto, Espinosa explica: “Assim, quando podemos ser a causa adequada de alguma dessas afecções, por afeto compreendo então uma ação; nos outros casos, uma paixão (Ética III, Definição 3)". Com isso compreendemos que embora sejam afecções do corpo (modo do atributo extensão), os afetos compreendem também as ideias dessas afecções (no atributo pensamento, do qual a mente é um modo).

Tal como defendemos em outros trabalhos ${ }^{6}$, esse último adendo acrescentado por Espinosa reúne todas as três definições numa só expressão: Uma paixão é dada, portanto, quando o homem é causa inadequada do que se produz dentro ou fora dele temos um afeto passivo ou uma paixão triste. De modo inverso, uma ação é dada quando o que se produz dentro ou fora do homem pode ser clara e distintamente conhecida ou compreendida apenas por ele - temos um afeto ativo ou uma paixão alegre.

Chaui (2005) aponta que Espinosa define paixão como "afetos ou sentimentos causados em nós por coisas ou causas exteriores a nós e das quais somos os receptores passivos" (p.101). A definição de afecção aparece como "toda mudança, alteração ou modificação de alguma coisa, seja produzida por ela mesma, seja causada por outra coisa" (p.98), argumentando que, na alma, as afecções do corpo se realizam como ideias afetivas ou sentimentos, derivando desse fenômeno o emprego de dois termos afecções e afetos - o que marca uma diferença entre eles.

Assim, quando Espinosa utiliza o termo affectus, ele está chamando a atenção para o estado em que se encontra o corpo em relação à potência de ação - alegria, tristeza... - diferentemente de affectio, que implica considerar o movimento dinâmico

\footnotetext{
${ }^{6}$ Um trabalho sobre o tema foi apresentado pela primeira vez no II Seminário de Epistemologia e Teorias da Educação, realizado de 11 a 13 de dezembro de 2006 na Faculdade de Educação da UNICAMP, sob o título: "A Teoria das Afecções de Espinosa na Construção do Estudo Histórico-psicológico da Teoria das Emoções de Vigotski" - em parceria com Fernando Bonadia de Oliveira, a quem agradeço pelos bons encontro que têm potencializado minhas reflexões.
} 
propriamente dito, em termos de atividade e passividade e a causa (adequada ou inadequada $)^{7}$.

Nesta parte III da Ética, convém ainda ressaltar os postulados que antecedem as proposições e que dizem respeito ao corpo humano. O primeiro afirma: "O corpo humano pode ser afetado de numerosas maneiras pelas quais a sua potência de agir é aumentada ou diminuída; e, ainda, por outras que não aumentam nem diminuem a sua potência de agir". E o segundo afirma: “O corpo humano pode sofrer numerosas transformações e conservar, todavia, as impressões ou vestígios dos objetos (...) e, consequentemente, as imagens das coisas (...)". Espinosa afirma ainda que ideia é afeto (Espinosa, Ética IV, Proposição 14).

Para Chaui (2005), no pensamento de Espinosa, o termo "ideia" assume dois sentidos principais:

a ideia como um conceito que nossa mente forma (ter ideia de alguma coisa); a ideia como a natureza de nossa própria alma (ser ideia do corpo e ser ideia de si mesma). Nos dois casos, porém, há um traço comum: uma ideia é um ato (ato do intelecto para ter ideia; e a existência da mente ou alma como força para ser ideia, isto é, um modo do atributo Pensamento). No sentido de ter ideia, há dois tipos de ideias: as imaginativas ou inadequadas e as intelectivas ou adequadas (p. 99 - grifos da autora).

Em meio a essas colocações, ponto a ser destacado nessa discussão é que a separação artificial entre ideia e afeto produz uma desintegração do processo emocional que implica a capacidade de afetar e ser afetado na relação dos processos de atividade e passividade que se produzem no ser humano - em seu corpo e mente concomitantemente.

Os afetos, assim, não podem ter em nós causa adequada ou total, na medida em que estão sempre relacionados a algo, a um objeto ou a uma pessoa, por exemplo. Por outro lado, os afetos não podem ter em nós causa parcial, porque estão sempre relacionadas com um sujeito que se emociona - nesse caso, nós mesmos. Há uma concepção dialética que se faz fundamental. Os afetos são, nesse sentido, da ordem do

\footnotetext{
${ }^{7}$ Tomando a Ética encontramos em nossos estudos, dois termos: affectus e affectio, que foram tidos como equivalentes (pois alguns tradutores tratavam ambas por afecção), mas parecem apontar coisas diferentes. Quando Espinosa utiliza o termo affectus ele parece estar chamando a atenção para o estado em que se encontra o corpo em relação à potência de ação - alegria, tristeza... - diferentemente de affectio que implica considerar o movimento dinâmico propriamente dito, em termos de atividade e passividade e a causa (adequada ou inadequada). Deleuze nos ajuda a compreender essa questão ao defender que há uma dinâmica de mútua implicação (1978) e assinala a importância da diferenciação de affectio e affectus, como dois termos que designam coisas diferentes. Quando se utiliza o termo "afeto" ele remete ao "affectus" de Espinosa, diferentemente de "afecção" que remete a "affectio" (traduzida no francês por affection) (Magiolino, 2010).
} 
encontro, da experiência e da relação entre os seres no mundo, com o mundo. Assim, a compreensão deste processo implica pensar que o conceito de affectio abarca ao mesmo tempo atividade e passividade, causa adequada e não adequada, afeto e ideia.

Mas é preciso esclarecer que os conceitos de passividade e atividade não estão, necessariamente, relacionados ao domínio da nossa vontade - como atestava Descartes. Esse, aliás, é um ponto crucial sobre qual, como vimos, incide a crítica de Espinosa a Descartes e, então aos autores que, nos mais diversos campos, acabam sendo trabalhados - ou cujos trabalhos acabam repercutindo - na educação.

Para Espinosa, os homens devem fugir da servidão como ilusão de liberdade para encontrar a liberdade propriamente dita. Isto o leva a pensar e desenvolver uma ética que se constitui no plano dos afetos, já que estes podem libertar ou escravizar.

A liberdade reside no fato de o homem poder tornar-se causa de sua alegria na medida em que conhece pela razão cada vez mais as causas de suas ações, e se desprende do domínio imaginativo (um modo de percepção mais imediato do mundo concreto). A ideia adequada das coisas - tomadas como essências singulares - é alcançada pela intuição intelectual.

Neste sentido, no princípio a consciência de si é apenas conhecimento confuso, relacionado aos efeitos de nossas relações exteriores, com os seres e com o mundo que nos cerca (Deleuze, 2002, Yovel, 1993). Esse conhecimento, imaginatio, segundo Yovel (1993), deve ser substituído por um conhecimento de segundo tipo, ou gênero, o conhecimento científico com o qual o homem se aproxima de seu próprio ser a partir do exterior.

Contudo, o conhecimento deste tipo não tem o poder afectivo necessário para me transformar e libertar. Para produzir tais efeitos, o conhecimento científico deve satisfazer duas condições. Primeiro, deve desde o início ser concebido e sentido como explicando uma verdade metafísica básica, a saber, a identidade da natureza com Deus e da essência individual com o Deus-natureza. Baseada, em última instância, na intuição intelectual, esta verdade está subjacente a todo processo científico. Segundo, o progresso científico discursivo deve eventualmente dar lugar à intuição sintética, acima descrita, que origina 0 poder afectivo suficiente para se apossar da nossa vida e transformar as nossas paixões. $O$ conhecimento científico está rodeado, por assim dizer, de ambos os lados, por estratos intuitivos: um, subjacente ao processo desde o início e o outro levando-o ao seu clímax (Yovel, 1993, p. 364). 
O conhecimento de si, desse ponto de vista, assume em Espinosa uma importante via para a emancipação, pedra angular em sua Ética. O homem compreende a si mesmo por uma via tortuosa e indireta.

Devo compreender o que são as coisas particulares; como é que o corpo está relacionado com a mente; como funcionam os corpos e como surgem os sentimentos; qual é a origem dos contextos sociais; e como é que meu próprio corpo, os meus sentimentos e as ligações sociais são determinadas pelo ambiente causal. Assim, decifro o meu próprio ser de fora, isto é, a partir dos padrões e das leis gerais que governam o universo. No entanto, no terceiro tipo de conhecimento, todas essas informações colhidas externamente se conjugam e se aglutinam na "essência" específica ou na explicação interna da unidade singular que eu sou. Neste ponto (bastante raro), tendo adquirido um conhecimento científico gradual sobre mim mesmo a partir de diferentes pontos de vista causais, sofro então uma transição intuitiva que, julga Espinosa, me permite ter uma opinião sinóptica sobre a minha existência singular, enquanto inerente a Deus e derivando internamente a partir de sua essência interna. As relações causais mediadoras foram interiorizadas e sintetizadas numa essência singular que se diz constituírem em relação à qual são equivalentes. Não existem quaisquer informações adicionais, apenas um novo entendimento e organização dos mesmos ingredientes cognitivos (Yovel, 1993, p. 364).

A vontade está relacionada a um certo modo de pensar e agir, de maneira que não é livre e absoluta como na doutrina cartesiana; Está intrinsecamente relacionada a motivos externos, às relações de afecção mútua, sendo governada por uma necessidade lógica absoluta - a causa da existência singular do homem é a existência de outros homens singulares que o produzem, de maneira que a existência de cada um pressupõe a existência do outro - e pela razão.

Na parte V da Ética, Espinosa aborda a potência da razão em refrear e regular os afetos através da liberdade ou beatitude da mente. Espinosa fundamenta e atesta o monismo que opõe seu pensamento ao de Descartes que, defende a união do corpo e da alma por meio da glândula pineal e que os afetos dependem totalmente da vontade e da razão que pode governá-los de maneira absoluta.

Para Espinosa os pensamentos e as ideias das coisas se ordenam exatamente como as afecções do corpo e as imagens das coisas no corpo. É nesse sentido que o homem tem o poder, ainda que parcial, de compreender os afetos desvinculando afeto de ideia de causa exterior e se vinculando a pensamentos verdadeiros. Nesse processo, por conseguinte, os afetos e os desejos deixam de ser paixão - uma ideia confusa - e tornam-se virtudes (Ética III, Proposições de 1 a 4, Escólio).

Espinosa vincula afeto e ideia. Ao fazer isso ele abre a possibilidade para pensarmos o processo emocional em sua complexidade: a relação corpo-mente e a 
relação sensação-expressão. A definição dos afetos, que se sintetiza na palavra affectio, o processo de afecção está, assim, intrinsecamente relacionado à transição, transitio. Essa ideia de modificação, transição, explicita a dialética dos afetos espinosanos. Pois, quando Espinosa diz que affectus é affectio e indagamos o que é, então, affectio, é necessário compreender que esse último remete à modificação.

$\mathrm{Na}$ definição de modo Espinosa afirma: "Por modo entendo as afecções da substância" (Espinosa, Ética I, Definição 5). A noção de afecção fornece a base para o processo dialético de "transformação das emoções".

Esse ponto constitui, para nós, objeto central de indagação que tem sido possível investigar no âmbito do teatro tomando o processo de afecção como a capacidade de afetar e ser afetado à medida que o ator sente expressa suas emoções.

\section{As emoções em cena}

Retomemos o paradoxo do ator explicitado antes para nos dedicarmos, agora, à emergência das emoções. Interessante que Damásio - neurocientista que vem tecendo críticas a Descartes e procurando assumir a contribuição de Espinosa no âmbito da neurologia contemporânea - se debate sobre esse paradoxo entre o sentir e o expressar ao retomar a indagação de Hamlet.

O ator não tem nenhuma causa pessoal para a sua emoção - o ator está falando do destino de um personagem chamado Hécuba e, tal como diz Hamlet, "o que é que Hécuba tem a ver com ele ou ele com Hécuba?". E apesar disso, o ator constrói na sua mente os pensamentos que lhe permitem desencadear a emoção e que o seu talento consequentemente refina (Damásio, 2004, p. 77).

Vigotski - que afirmava já na primeira metade do século passado, que o futuro da neuropsicologia dependia de Espinosa - também se debatia sobre os dilemas hamletianos e sobre o paradoxo do ator em vivenciar, experienciar ou não uma emoção Em um de seus últimos trabalhos, acerca do problema do trabalho criativo do ator, Vigotski (1987) retoma os trabalhos de Diderot, Stanislávski e Ribot.

Vigotski (1987) aponta que o filósofo Diderot, em seu Paradoxo do Comediante, comentando o trabalho de algumas atrizes famosas na época, defende que as paixões reais do ator não eram absolutamente necessárias para uma boa atuação. Stanislávski, ao contrário - adverte Vigotski - elabora métodos de atuação que consistiam em levar o ator a trazer à tona uma justificação interna da ação a ser desenvolvida ou a descoberta 
de uma verdade dos sentimentos no palco. Vigotski assinala, por fim, uma posição intermediária, de certa forma, no campo da psicologia das emoções assumida por Ribot que substitui o dualismo com uma hipótese monista de paralelismo e interação.

Dessas elaborações no campo do teatro e das investigações sobre os mecanismos psicofisiológicos das emoções, o que Vigotski vai ressaltar é o fato de que todas atestam a impossibilidade do domínio e da evocação voluntária das mesmas. Esse processo "não é baseado na interferência direta de nossa vontade na esfera das sensações do [mesmo] modo que isto ocorre na área do pensamento e do movimento" (Vigotski, 1987, p. 243 tradução nossa). Com isso, Vigotski - cuja obra se fundamenta na filosofia de Espinosa - coloca em xeque algumas das ideias que fundamentam a doutrina cartesiana e aponta a necessidade da criação de um complexo sistema (de ideias, conceitos, imagens...) para que se possa dar um sentido ao próprio sistema e à expressão das emoções no campo da arte - o que nos leva a indagar sobre o processo de significação das emoções e problema do domínio do comportamento na esfera da vida cotidiana.

Notamos que tais discussões trazem em seu bojo o problema das emoções e de sua expressão, manifestação e possibilidades de (in)diferenciação nas experiências vividas, nas relações estéticas e éticas. As emoções experienciadas na vida assemelham-se àquelas que vivenciamos na arte?

Diversos autores vão se deter nessa questão que vimos debatendo em outros trabalhos (Magiolino, 2010, 2011), nos quais apontamos as dificuldades em explicar as especificidades das reações estéticas e sua (não) contraposição às emoções ou aos sentimentos reais. A principal especificidade seria de as emoções estéticas não despertarem em nós o desejo ou a vontade de agir. Tanto no jogo do "faz-de-conta" infantil como nos processos de representação artística ocorre uma determinada retenção da reação emocional e o sentimento artístico se constitui e se mantém por meio da imaginação, que o reforça (Bakhtin, 2002; Vigotski, 2001).

Vigostski vai apontar a especificidade do sentimento artístico, da reação estética e fundamenta sua elaboração sobre o conceito de catarse - sem se limitar ao conceito de Aristóteles. Essa problematização da catarse contribui para redimensionar o aspecto central da natureza da reação estética:

[...] a base da reação estética são as emoções que suscitadas pela arte e por nós vivenciadas com toda realidade e força [...] retém-se e recalca-se extraordinariamente o aspecto motor externo da emoção, e começa a parecer que experimentamos apenas 
sentimentos ilusórios. É nessa unidade de sentimento e fantasia que se baseia qualquer arte (Vigotski, 2001, p. 272).

Em sua perspectiva a arte como "técnica social do sentimento" assume um papel central como um poderoso meio de transformação e elaboração das emoções e a ênfase recai sobre a "complexa transformação dos sentimentos" (Vigotski, 2001, p. 112).

Lukács - outro autor que também se detém no conceito de catarse - entende que a catarse não é uma categoria puramente estética, sua origem estaria na vida dos seres humanos e que a obra de arte reelaboraria os conteúdos extraídos da vida, dando-lhes uma nova configuração que superaria o imediatismo e o pragmatismo da cotidianidade. Com relação a isso, é interessante acompanhar a argumentação do próprio Lukács (1970) sobre a função da arte na vida e personalidade humana:

Já na ética de Aristóteles encontramos tendências que apontam para esta direção, mas somente Spinoza formulou com clareza, em primeiro lugar, o problema decisivo para a concepção aqui adotada da subjetividade humana: "um sentimento não pode ser contrariado ou supresso senão por um sentimento contrário e mais forte que o sentimento que a contrariar". Quando falarmos, aqui e posteriormente, de uma elevação da personalidade, deve ser sempre entendida no sentido de Spinoza (p.185 - grifos nossos).

Como vimos argumentando em outros trabalhos no âmbito da pesquisa de pósdoutoramento, a filosofia espinosana, está na base das elaborações desses dois autores Vigotski e Lukács - que se dedicam a essa complexa transformação de sentimentos (transitio, affectio) operada pela obra de arte. A arte, para Espinosa, estaria no âmbito de um conhecimento mais complexo, um terceiro gênero de conhecimento que é inventivo e se dedica a criar o novo, novos modos de vida, ação e criação.

Com base nessas ideias e afetos de fundo espinosano o trabalho do ator emerge como lócus de investigação privilegiado da dinâmica das afecções na medida em que 
possibilita o jogo e vivenciamento de papeis mediante o trabalho de (re)elaboração e (re)significação das emoções.

Trazemos, nesse momento, alguns trechos da pesquisa de campo ${ }^{8}$ realizada na sala de ensaio de um grupo de teatro de São Paulo que vem desenvolvendo um trabalho de pesquisa artística que enfoca o papel da memória, das emoções e do imaginário na constituição do ator ${ }^{9}$, realizando diversos exercícios - como a imersão ${ }^{10}$.

Num desses exercícios, o sentimento de vingança emerge e é trabalhada tomando por base as experiências pessoais das atrizes envolvidas. O exercício de Lorena ${ }^{11}$ é tomado como objeto de reflexão no presente trabalho.

\section{Na sala de ensaio}

O exercício começa com as atrizes movimentando-se pela sala de ensaio. Os braços, as pernas, a cabeça são agitados de maneira frenética. O diretor diz: "Olha bem de frente. Encara. Que é isso? O que é isso que você quer arrancar de você?". Os movimentos se tornam menos frenéticos e os gestos mais bem delineados. Cada uma das atrizes vai parando em um canto da sala. Lorena gira os braços lentamente em torno de si, depois leva as mãos à cabeça, puxa os cabelos e diz: "Sai daqui", repetidas vezes. Ela vai descendo uma das mãos até o peito e outra permanece contra o ventre. Como se portasse um punhal, golpeia o peito com fortes batidas. Em seguida, ela diz: "Fica... fica aí que eu acho que eu preciso...". Ela junta as duas mãos no peito, olha para cima e diz: "Fica, pode ficar". Silêncio. "Como ia ser se não tivesse isso? O que ia ter no lugar disso? Num ia ter nada!" [...] "Ai... mas como eu queria que saísse". Com os olhos fechados ela leva as mãos ao peito e depois vai retirando-as, lentamente para, em seguida, esfregá-las. Então ela diz: "Ah, mas eu tô esperando o dia que eu vou perder o controle e que eu vou sim

\footnotetext{
${ }^{8}$ A pesquisa de pós-doutorado foi desenvolvida no Programa de Estudos Pós-Graduados em Psicologia Social da PUC-SP, sob supervisão de Bader Burihan Sawaia - a quem agradeço, sobretudo, pela profícua interlocução. O projeto, intitulado Emoções no processo de organização dramática do psiquismo transformação e significação nas relações éticas e estéticas, contou com apoio da FAPESP.

${ }^{9}$ Trata-se da Cia. de Teatro Fábrica São Paulo que autoriza a divulgação de seu nome e, em seus quase trinta anos de existência, vem realizando uma pesquisa que foi contemplada por quatro vezes pelo Programa Municipal de Fomento ao Teatro para a Cidade de São Paulo. Na última edição em que o grupo foi contemplado o processo resultou na publicação de um livro sobre o processo de pesquisa artística no qual a pesquisadora, então doutoranda, discute as ideias de Vigotski no processo de criação.

${ }^{10} \mathrm{O}$ exercício se baseia no fato de que: “[...] os atores são convidados a revisitarem lugares onde se alojam momentos significativos de sua vida. Movimentando-se por esses espaços reconstruídos pela memória, os atores passam a reagir aos estímulos oriundos do período em que habitavam aquele lugar. Mergulhados nessa espécie de devaneio, têm como companheiros os outros atores também imersos. Esse fator permite que todos sejam afetados ao mesmo tempo, tanto por seus próprios conteúdos internos, como também pelos outros que se movimentam, gesticulam e se expressam no espaço compartilhado da sala de treinamento. É importante ressaltar que não se trata de apenas relembrar fatos, pensar sobre o que foi ou é significativo, mas de reconstruir um espaço proposto para então ser afetado e interagir fisicamente com ele. É nesse sentido que dizemos que os exercícios de imersão propõem a entrada física na memória" (Texto do Projeto de Pesquisa Artística da Cia. de Teatro Fábrica São Paulo, coordenada pelo diretor Roberto Rosa, mimeo, 2009).

11 Trata-se de um nome fictício. Embora a Cia. autorize a divulgação de seu nome, com relação aos sujeitos que integraram a pesquisa, tomamos a decisão de manter o sigilo.
} 
deixar sair tudo. E você vai ficar aí paradinho ouvindo tudo". Sua expressão muda: "Você pensa tudo errado". "Você não sabe de nada". Alterando a voz, ela grita: "Você não tem noção do quanto você não é nada!". "Você num sabe, mas eu num tenho mais ouvidos pras suas mentiras. Eu num escuto mais o que você diz. Eu finjo que eu escuto". Ao dizer isso ela tapa os ouvidos com as duas mãos e continua: "Eu finjo... Eu sorrio pra você porque eu sou uma menina bem educada! Eu sorrio pra você, porque eu tenho o mínimo de respeito, porque a minha mãe mandou ter! Por mim eu não teria... porque você não merece!" O diretor entra cuidadosamente na sala e vai colocando alguns objetos no chão. Ela caminha até deparar-se com um dos objetos e diz: "Mas hoje eu posso!". Ela vira-se para um lado e o aponta como se fosse uma arma. Faz movimentos como se estivesse preparando o gatilho, dá dois passos e diz: "Um dia eu tive essa oportunidade e você nem sabe!"... "Mas e hoje? Porque eu num faço?". Lorena olha para a suposta arma e diz: "Aquele dia eu num fiz porque eu fiquei com medo... com pena. Porque eu pensei na sua família, porque eu pensei na minha vida... Mas hoje eu posso! Senta aí! Cala a sua boca! Ou melhor, fala, fala!... Não acredito. Não acredito! Eu sei que é mentira.” [...] Não, não é tão simples assim... Eu quero que você entenda o que tudo isso acarretou... [...] Agora me peça perdão por tudo que isso acarretou". Após alguns instantes, Lorena joga o objeto metálico no chão (Transcrição de exercício de imersão videogravado).

Lorena se depara com uma indagação digna de Hamlet: devo ou não matar aquele que odeio/amo/respeito? A atriz - como o ator evocado por Hamlet - procura experienciar, vivenciar o afeto em seu corpo-mente e expressá-lo em seus gestos e palavras e, com isso, consegue forçar a sua alma a sentir o que ela quer?

No processo de imergir em si mesma, diversos afetos emergem. São diversos afetos que transbordam, nos movimentos que se desdobram em seus gestos e palavras que escapam como areia entre os dedos das mãos ou que se atiram em direção ao outro imaginário, como um punhal. Lorena chora, grita, bate, faz o gesto de arrancar os cabelos. A sensação é, a todo o momento, relacionada a uma ou a muitas expressões. Ao mesmo tempo em que essa sensação vai se colocando em gestos, expressões e palavras, ela começa a tocar os seus dentes e emerge a ideia de arrancar: o movimento de afetivo toma corpo, se faz visível.

De fato, ela trabalha experienciando as emoções em seu corpo e mente e, então, construindo modos de as (re)colocar em cena. As emoções assumem determinadas expressões que as qualificam como tal: o corpo se fecha, a cabeça está inerte, o tônus perde a rigidez. A mão é levada ao peito... Angústia? Rancor? Em seguida, as mãos são levantadas, ela esfrega uma na outra e grita: "Você não tem noção do quanto você não é nada!"... O corpo todo se pronuncia, o tônus rijo se faz notar nos músculos do braço, no pescoço que vibra... Raiva? Revolta?

Como parte de seu métier, a atriz desenvolve a arte (no grego, techné) de esculpir em seu corpo as emoções propriamente ditas? 
Para enfrentar essa questão, que está no cerne de nosso debate, se faz necessário trazermos outros elementos. Depois do exercício de imersão, ocorre um acalorado debate sobre as experiências vivenciadas no mesmo - a "roda de observação". Trazemos aqui alguns trechos das falas videogravadas, no intuito de dar visibilidade à dinâmica de afecções - a sensação e a expressão - e às impossibilidades de transformação e elaboração dos afetos.

Lorena: [...] eu comecei com uma coisa no corpo de "num sai daqui", "num sai daqui", "nada sai daqui", "eu num deixo sair daqui", "nada sai daqui" (começa com a mão no peito e vai subindo uma de cada vez ao mesmo tempo em que pronuncia a frase "não sai daqui", até chegar na boca e fechá-la com as duas mãos)... eu cheguei na boca: "nada sai daqui". E aí eu comecei a tocar os meus dentes e começou a vir uma ideia de arrancar, mas arrancar porque eu não podia deixar sair de outra forma, num podia deixar sair em forma de... palavra.." (Roda de observação)

Lorena: Eu tava trabalhando com a coisa do rancor, né? Que era o que você quer tirar de você e não consegue. E aí, era uma... era uma sensação como se esse rancor fosse uma pedra (leva a mão ao peito) dentro de mim assim, de tão fixa e forte que ela tá lá dentro, sabe?... Então é uma coisa meio impossível de tirar, porque é um concreto [...]. E aí eu acho que esse bater no peito era... era meio... era bater nisso assim...

[...] Lorena: A coisa do controle é muito forte, né? Pra mim a coisa do autocontrole é muito forte. Muitos momentos na vida...

Pesquisadora: Controlar o que sente?

Lorena: É. (pausa) Não controlar o que sente, controlar o que eu faço. Eu sempre me sinto muito livre pra sentir tudo o que eu sinto, assim. Eu num fico me reprimindo nesse sentido. Mas controlar o que eu faço. Tipo, às vezes, eu tô morrendo de raiva de alguém, mas eu fico na minha, não falo nada, sabe? Isso acontece muito assim. Então, essa palavra "autocontrole", tem uma hora aí que eu começo a gritar "autocontrole, autocontrole..." [...]Pesquisadora: Qual a diferença, assim, de controlar o que você sente e o que você faz?

Lorena: Eu acho que não é nem uma questão de controlar o que sente, porque eu nu... num sei nem se isso é possível... Mas eu acho que, muitas vezes, as pessoas tentam... não sabem nomear o que elas sentem ou num querem admitir que elas tão sentindo alguma coisa... Tem sentimentos que são muito tabus, assim... né? Tipo, sentir inveja... As pessoas não admitem assim, de forma alguma, que sentem inveja de alguém... E mesmo sentir raiva, sentir ódio... tem essa coisa né? Ah faz mal, não pode, é ruim... cê tem que ser alegre, cê tem que ser uma pessoa feliz. E... ah, eu num tenho isso assim... eu acho normal sentir raiva, sentir ódio... eu sinto mesmo. Agora... a questão das ações, aí é... aí cê já pensa um monte de coisas né? Às vezes, cê tem... sei lá... é uma pessoa da tua família, cê... num... cê também sente uma certa... né? Ou você gosta da pessoa, ou você tem pena de f..., de dizer certas coisas pra ela... Ou você num quer tornar a convivência uma coisa impossível também... [...]tem mil motivos pra você se controlar assim.

[...] Lorena: É que tem vários momentos do rancor, mesmo na vida, né? Tem momentos parecidos com esse até que são... num sei por que cê vai entrando numa série de pensamentos e lembranças, que vai te despertando isso, mas cê tá, sei lá, em casa, sentado no sofá, sozinho... E tem os momentos que cê tá em contato com a pessoa e ela te diz alguma coisa ou te faz alguma coisa... que te desperta, de repente, assim... E... quando isso acontece, essa coisa de despertar de repente, é uma sensação que... que eu acho que é no corpo todo assim, parece que o sangue muda de temperatura, sabe? E é no corpo inteiro assim. Quando num... quando é através do pensamento assim, de... de ficar 
resgatando fatos, lembranças, aí sim eu acho que é mais essa sensação da... do concreto (Transcrição dos trechos de Auto-confrontação videogravados).

Notamos a complexa dinâmica afetiva que a atriz vivencia quando, Lorena, ao ser confrontada, procura colocar em palavras como esse processo ocorre: começa com algo que acontece no corpo, que não pode sair - "não sai daqui", "eu num deixo sair daqui, nada sai daqui” - até chegar à boca e fechá-la com as duas mãos. Lorena busca por um acabamento estético, e leva as marcas da sensação e os contornos de sua expressão para a cena da personagem em questão: ela coloca as mãos no peito, sobe as mãos pelo pescoço até chegar à boca, ela tenta arrancar os dentes e fecha a boca com as mãos: o rancor (que ela sente como pedra de concreto) toma forma em seu corpo. Vamos percebendo como ela vai aprimorando a técnica de reconhecer o que/como sente e expressar isso que sente. Sentir e expressar se interpenetram e se separam, são duas dimensões possíveis do/no processo de afecção com as quais a atriz aprende a lidar isto faz parte de seu métier.

Contudo, em sua vida, como isso tudo se passa?

Poderíamos começar por apontar as diferenças que se (re)produzem nas experiências éticas e estéticas nas últimas palavras de Lorena, aqui transcritas: "[na vida] tem momentos parecidos com esse até que são... cê vai entrando numa série de pensamentos" e "tem os momentos que cê tá em contato com a pessoa e ela te diz alguma coisa ou te faz alguma coisa... que te desperta" numa "sensação que é no corpo inteiro". Contudo, sem perder de vista a advertência de Espinosa sobre o significado dos vocábulos, (re)tomaremos como ponto de partida, suas definições no intuito de, mais do que identificar os afetos e seus significados, dar visibilidade a dinâmica de afecção.

Lorena parece tomada pela ira e pelo desejo de vingança, num primeiro olhar para a cena. Vislumbramos um desejo que a incitaria, por ódio, a fazer mal a quem, supostamente ela odeia - seu pai. Também por ódio ela desejaria fazer mal a esse que lhe causou dano. Todavia, ela encontra-se, dramaticamente, entre o amor e o ódio, a consideração e a desconsideração, o agradecimento e a indignação. Pois, há um sentimento de respeito e consideração, de amor pela sua mãe, que potencializa (ou não) seus atos e redimensiona sua indignação pelo pai. O estado de Lorena, no intenso 
embate entre as emoções igualmente potentes, nos remete à flutuação da alma, concebida por Espinosa. Ao criar e vivenciar uma situação imaginária de vingança em que toda, ou quase toda, a rede causal emerge o ódio pode ser sentido e expresso em toda a sua potencialidade, por meio de palavras que, como vimos apontando, trazem valores e imagens socialmente construídas que influenciam o seu modo de sentir, (não se) expressar e agir: "eu sou menina bem comportada", "te considero e te respeito porque a minha mãe mandou".

Ao vivenciar os afetos em seu corpo-mente Lorena, ao tomar consciência e, depois, conhecer efetivamente seus afetos - pelas modificações corporais/mentais, mas também pelos gestos, palavras dos outros nas experiências sociais da roda-deobservação, da auto-confrontação ${ }^{12}$ - redescobre uma intrincada trama de relações com o sujeito que é alvo de sua raiva e rancor: indignação, raiva, ódio... amor. Assim como Hamlet, Lorena não consegue levar a cabo a experiência, ainda que imaginária, de vingança. Ela deseja, num primeiro momento, se vingar, fazer sofrer, matar... mas não pode ou não deve matar aquele a quem deve respeito ou amor: o pai. Deparamo-nos, aqui, com um fato patente na experiência (est)ética vivida, ao qual Espinosa se deteve em suas elaborações: um afeto só pode ser transformado por um outro afeto.

Lorena é enfática com relação a outro ponto: “tem sentimentos que são muito tabus". E aponta a dificuldade com relação à inveja, raiva e ódio: "As pessoas não admitem assim, de forma alguma, que sentem inveja de alguém" e "sentir raiva, sentir ódio... tem essa coisa né? Ah faz mal, não pode, é ruim... cê tem que ser alegre, cê tem que ser uma pessoa feliz".

Inveja, raiva e rancor são emoções ou, em suas palavras, "sentimentos" que, $a$ priori, consideramos "tabus" negativos e que, por essa razão, devem ser evitados, controlados, eliminados, expurgados. No campo da educação e, mais especificamente em sua intersecção com a psicologia, como vimos anteriormente, há uma ampla variedade de programas e atividades sobre como sanar e trabalhar emoções negativas. Nesse movimento, expressar emoções, sobretudo, as consideradas negativas, parece ser sinônimo de não senti-las.

\footnotetext{
${ }^{12}$ No projeto de pesquisa desenvolvido inspiramo-nos na abordagem metodológica de Clot (2009) que prevê a utilização da auto-confrontação simples e/ou cruzada. Tal procedimento consiste, de maneira muito breve, na videogravação da atividade e análise da mesma pelo trabalhador e seus pares com a intervenção do pesquisador.
} 
Agora, aprender a identificar emoções, sentimentos e afetos e não expressá-los é a mesma coisa que deixar de senti-los? Sentir e expressar estão intrinsecamente articulados? É possível deixar de sentir ao deixar de expressar?

Para a atriz não se trata de controlar o que se sente, mas controlar as ações num determinado contexto de afetação:

Agora... a questão das ações, aí é... aí cê já pensa um monte de coisas né? Às vezes, cê tem... sei lá... é uma pessoa da tua família, cê... num... cê também sente uma certa... né? Ou você gosta da pessoa, ou você tem pena de f..., de dizer certas coisas pra ela... Ou você num quer tornar a convivência uma coisa impossível também....

Podemos compreender na/pela experiência de Lorena, que os afetos vividos não têm, então, um sentido positivo ou negativo e, tampouco, um estatuto independente das relações entre os corpos e os sujeitos - como bem nos mostra a filosofia espinosana. E, por outro lado, podemos compreender que não se trata de controlar o que se sente - uma busca de controle total dos afetos que ainda nos remete a Descartes - mas, quando muito, o que se consegue (ou não) expressar.

\section{Na sala de aula}

Era dia das mães. A professora, tendo que seguir o calendário de datas comemorativas da rede [municipal de ensino], seleciona atividades para a turma. Uma questão se colocava: como trabalhar essa data na sala de aula com Vitor? O menino, repetente, estava envolvido em confusões e desavenças, como a que acabara dando um soco num colega em plena sala de aula porque ele ofendera a sua mãe. Vitor perdera a mãe ao nascer, fora abandonado pelo pai que era usuário de drogas, morava com o tio que era um conhecido traficante do bairro, e era "criado" pela a avó, que vinha frequentemente bêbada às reuniões na escola. Acostumada a trabalhar com o teatro na sala de aula, a professora decide, então, dramatizar um texto sobre a mãe do Frankenstein ${ }^{13}$. No momento em que termina a leitura, Vitor levanta a mão dizendo que quer fazer o papel do monstro biônico que, na história sentia-se complexado por não ter mãe e pede ao cientista para criar uma. Divididos os personagens, a dramatização é iniciada. Ao abraçar a colega que faz o papel de sua mãe o menino se emociona. Ele olha para a professora com lágrimas nos olhos e um sorriso no rosto. As crianças, ao contrário, riem de sua interpretação tragicômica. Como de costume, as crianças logo se sentam e a interpretação oral do texto se inicia num debate acalorado. As crianças tocam em diversos pontos, mas uma das meninas, a que fizera o papel da mãe ressalta: "Prô, eu acho que o Frank não devia se sentir complexado por não ter mãe". Vitor inclina-se na carteira e arregala os olhos. A professora incita a aluna a prosseguir. "Não é só a mãe que cuida, tem muita gente importante". Outros alunos dão sequencia à discussão e, um deles, ressalta a importância dos amigos. Ao final da aula, Vitor procura a professora pra dizer que gostou muito da história e do teatro que fizera (Trecho recortado de diário de campo).

${ }^{13}$ Trata-se do poema Quatro historinhas de horror, de José Paulo Paes. 
Descobrimos aqui, nessa situação de sala de aula, um garoto como "arruaceiro clássico" de Goleman?

Como em Hamlet, em certa medida, como em Lorena, Vitor - cuja situação vivida nos serviu de epígrafe na abertura desse ensaio - experiencia uma raiva que se desdobra um potente desejo de vingança. Vitor - que não se conformara em ver a mãe, que morrera em seu parto, ser ofendida - agredira o colega na situação anteriormente apontada. Não havia um distúrbio de percepção que o leva a interpretar erroneamente a situação. Não se tratava, tampouco, de uma mera crise de explosão emocional. Havia, sim, uma complexa dinâmica de afetação que culminou com uma situação de agressão.

A professora, por sua vez, procura criar um meio de enfrentar o problema. A estratégia utilizada, contudo, não é a de apenas falar ou escrever sobre a situação ou o afeto; tampouco, limita-se a fazer parar e pensar nas consequências ou ainda elaborar um projeto para trabalhar valores e moralidade. A professora, ao compreender essa dinâmica, procura retomá-la através da dramatização de um texto literário. Não aparece, ao menos aqui, a ideia de ensinar a controlar as emoções, eliminar as emoções, sentimentos e afetos negativos, a ideia de domar a agressão. Mas, poderíamos dizer, de experienciar a dinâmica de afecção em termos de passividade e atividade, de compreender a rede causal e, finalmente, de conhecer os afetos para moderá-los?

E, é nesse movimento de abertura à experiência e ao (re)conhecimento, que Vitor inclina-se na carteira e arregala os olhos quando uma das meninas, ao dizer "Prô, eu acho que o Frank não devia se sentir complexado por não ter mãe", toca num ponto crítico: a perda da mãe, a decepção, o rebaixamento, a saudade... $\mathrm{Na}$ origem desses afetos, ou paixões, estaria, de acordo com Espinosa, a tristeza: "a passagem do homem de uma perfeição maior para uma perfeição menor" (Espinosa, Ética III, definição 3). Essa tristeza, nesse caso, poderia restringir, diminuir a sua potência de ação e, por conseguinte, cercear a sua relação com os colegas e o conhecimento.

A professora incita a aluna a prosseguir e ela é enfática: "Não é só a mãe que cuida, tem muita gente importante". Nas e pelas palavras dos outros, Vitor, que experienciou os afetos em seu corpo e mente - dramatizou, encenou, se emocionou, refletiu - toma conhecimento de seus afetos. Ao final da aula, ele procura a professora pra dizer de sua alegria. Vitor, não apreende a fazer com que a sua alma sinta o que sua vontade quer na ilusão cartesiana de que, com isso, as paixões estejam totalmente controladas e sanadas. 
O teatro e sua relação com o jogo e a brincadeira no processo de desenvolvimento humano, não apenas comunica ou suscita emoções e sentimentos, mas abre a possibilidade de colocar em cena, de objetivar as con(tra)dições e de, com isso, (trans)formá-los na dinâmica social e pessoal. Afinal, sentir e expressar - como na atividade estética que se explicita no trabalho do ator - não precisam, necessariamente, acontecer de maneira concomitante. Aprende-se a reagir, a sentir e a expressar de maneira que esses processos se separam ao longo do desenvolvimento.

Nos encontros entre/com os corpos a potência (de ação) se explicita, no/pelo desenvolvimento concomitante do modo segundo os dois atributos:

Aquilo que dispõe o Corpo humano de tal maneira que possa ser afetado de diversos modos ou que o torna apto a afetar os corpos externos de um número maior de modos é útil ao homem; e é-lhe tanto mais útil, quanto o Corpo se tornar por essa coisa mais apto a ser afetado de mais maneiras ou a afetar os outros corpos; e pelo contrário, é-lhe prejudicial aquilo que torna o Corpo menos apto para isto" (Espinosa, 1992, Ética IV, proposição 38).

O teatro permite uma mudança de lugar, de posição social. Ao brincar, nesse jogo de faz-de-conta, ao dramatizar a criança não apenas identifica expressões de afetos, mas os (re)conhece em seu corpo e mente, experienciando-os em sua complexidade, na trama das ideias, conceitos, imagens e valores dos quais as emoções tomam parte. Essa experiência possibilita um desenvolvimento da capacidade afetar e ser afetado. A criança, o sujeito torna-se ativo em meio às paixões.

É, nesse sentido, que o teatro (como a arte) poderia ser compreendido como uma técnica social das emoções - no sentido que Vigotski, afetado pelas ideias de Espinosa, lhe conferia - que vai além de um trabalho de cunho estritamente cognitivista com as emoções que irrompem na sala de aula.

\section{Algumas considerações}

Abordada nas mais diversas áreas da ciência e do conhecimento - Biologia, Antropologia, Psicologia, Filosofia, Neurologia - a questão da afetividade tem se configurado como um dos problemas mais debatidos na Educação, se levarmos em conta, especialmente, as relações de sala de aula e o processo de ensino e aprendizagem.

Tematiza-se a emoção na sala de aula, enfatiza-se a necessidade de se levar em conta a afetividade na relação professor aluno - sobretudo, na Educação Infantil e no Ensino Fundamental - proclama-se o afeto como solução dos problemas educacionais e 
prescreve-se metodologias de ensino e atividades para se trabalhar e controlar as emoções.

Em meio a contribuições produzidas na área, se faz notar ainda a ausência de uma reflexão sobre os fundamentos teóricos e conceituais, sobretudo, das práticas em voga. Ao retomar algumas das tentativas de enfrentamento da problemática, vamos percebendo que, embora haja uma contribuição no fato de apontarem que afeto e cognição são importantes no desenvolvimento humano, a ideia de controle das emoções é bastante forte em parte das estratégias de intervenção. E, com relação a estas, embora haja soluções criativas, a maioria delas incide no fato de treinar, desenvolver competências e habilidades, dominar e controlar por meio de estratégias estritamente cognitivas que desvelam uma fundamentação cartesiana.

Nessa esfera, a elaboração de Espinosa sobre afeto e afecção e as (im)possibilidades de domínio da conduta emergem como algo fundamental. Ao tomar essa elaboração como objeto de reflexão, procuramos argumentar sobre a possibilidade de compreender a experiência subjetiva da sensação e expressão dos afetos que implica conhecimento. Com/pelo conhecimento racional haverá não o controle, mas uma moderação possível dos afetos relacionada ao que pode a "potência da razão" moderare - em termos espinosanos.

Nesse movimento, compreendemos que o processo se dá mediante a relação de afecção dos corpos em relação com/na natureza, em decorrência do fato de os afetos aumentarem ou diminuírem a potência de agir. Ao nos inspirarmos nas ideias de Espinosa podemos vislumbrar um modo de conceber os afetos que não parte da classificação a priori ou da polarização entre positivos e negativos, tampouco subentende uma conotação moral que prega o controle - elementos que marcam as produções na área educacional.

Nesse sentido, o trabalho cotidiano do ator de teatro no exercício de sua profissão - a maestria da função afetiva ou emotiva e sua expressão - e a dramatização dos afetos na sala de aula abrem novas picadas no caminho para uma educação que não se fundamenta no controle, mas no conhecimento e no desenvolvimento das emoções, uma educação sensível e expressiva - algo que poderíamos, ainda que timidamente nesse momento, chamar de uma pedagogia da expressão do afeto ou da afecção expressiva.

Nessa perspectiva, Vitor, não é mais um garoto tido como valentão na escola, o “arruaceiro clássico" de Goleman que seria, segundo o autor, visivelmente perturbado, 
portador de "distorções perceptivas". A professora não se preocupa em ser afetiva para suprir, com isso, uma suposta carência do aluno e, com isso, levá-lo a aprender. Tampouco, ela se dedica a uma preleção moral ou ao exercício da punição e estigmatização. Podemos dizer que a prática e as estratégias pedagógicas não remetem a tentativas de domar a raiva ou a ira, como se estas fossem algo da ordem do incontrolável, do imponderável ou como querem alguns, do irracional ou do animal que habita o humano, mas ao conhecimento, vivenciamento e expressão do afeto que faz parte da condição humana.

\section{Referências Bibliográficas}

ARANTES, V. A. (Org.). (2003). Afetividade na escola: alternativas teóricas e práticas. São Paulo: Summus.

BAKHTIN, M. (2003). Estética da criação verbal. São Paulo, Martins Fontes.

CHAUI, M. (2005) Espinosa: uma filosofia da liberdade. São Paulo: Moderna.

CLOT, Y. (2009). Le pouvoir d'agir. Paris: La Dispute.

DAMÁSIO, A. (2004). Em busca de Espinosa: prazer e dor na ciência dos sentimentos. São Paulo: Companhia das Letras.

DARWIN, C. (2000). A expressão das emoç̃es no homem e nos animais. São Paulo: Companhia das Letras.

DELEUZE, G. (2002). Espinosa: filosofia prática. São Paulo: Escuta.

DESCARTES, R. (1988). Discurso sobre o método, As paixões da alma. In Os pensadores: Descartes, vol. I. São Paulo.

ESPINOSA, B. (2008). Ética. Belo Horizonte: Autêntica.

GOLEMAN, D. (2005). Inteligência Emocional. Rio de Janeiro: Objetiva.

KOYRÉ, A. (1987). Do mundo fechado ao universo infinito. Rio de Janeiro: Forense Universitária.

LEITE, S. A. S. (Org.). (2006). Afetividade e práticas pedagógicas. São Paulo: Casa do Psicólogo. LUKÁCS, G. (1970). Introdução a uma estética marxista. Rio de Janeiro: Ed. Civilização Brasileira.

MAGIOLINO, L. L. S. (2011) As emoções humanas nas experiências vividas: transformação e significação nas relações (est)éticas. In: SMOLKA, A.L.B.; NOGUEIRA, A. L. H. (Org.). Emoção, memória, imaginação na constituição do desenvolvimento humano. Campinas: Mercado de Letras, vol. 2, p. 35-56.

MAGIOLINO, L. L. S. Emoções humanas e significação numa perspectiva históricocultural do desenvolvimento humano: um estudo teórico da obra de Vigotski. 2010. Tese (Doutorado em Educação). UNICAMP, Faculdade de Educação, Campinas- SP.

VIGOTSKI, L. S. (1925/2001). Psicologia da arte. São Paulo, Martins Fontes. 
VYGOTSKY, L. S. (1932/1987). The Collected Works of L.S. Vygotsky, Scientific Legacy, New York..

YOVEL, Y. (1993) Espinosa e outros hereges. Lisboa: Imprensa Nacional - Casa da Moeda. 